\title{
HEALTH-RELATED QUALITY OF LIFE AND EXPECTATIONS OF PATIENTS BEFORE SURGICAL TREATMENT OF LUMBAR STENOSIS
}

\author{
QUALIDADE DE VIDA RELACIONADA À SAÚDE E EXPECTATIVAS DE PACIENTES ANTES \\ DO TRATAMENTO CIRÚRGICO DA ESTENOSE LOMBAR
}

\section{CALIDAD DE VIDA RELACIONADA CON LA SALUD Y EXPECTATIVAS DE LOS PACIENTES ANTES DEL TRATAMIENTO QUIRÚRGICO DE LA ESTENOSIS LUMBAR}

Lílian Maria Pacola', Eliane Nepomuceno², Rosana Aparecida Spadoti Dantas², Herton Rodrigo Tavares Costa', Débora Cristine Previdé Teixeira da Cunha², Carlos Fernando Pereira da Silva Herrero ${ }^{1}$, Helton luiz Aparecido Defino ${ }^{1}$

\begin{abstract}
Objective: To evaluate the expectations of patients awaiting surgical treatment of lumbar canal stenosis and the association of Health-Related Quality of Life (HRQoL) with symptoms of anxiety and depression. Methods: The sample included 49 patients from a university hospital. HRQoL was assessed by the Oswestry Disability Index (ODI) and 36-item Medical Outcomes Survey Short Form (SF-36) and symptoms of anxiety and depression by the Hospital Anxiety and Depression Scale (HADS). Expectations were investigated by means of questions used in international studies. Data were analyzed descriptively and by Student's t test. Results: The mean time of disease progression was 34.5 months, the mean age was 58.8 years and $55.1 \%$ of the patients were women. Most patients had the expectation of improving with surgical treatment and $46.9 \%$ expected to be "much better" with regard to leg pain, walking ability, independence in activities and mental well being. The scores of anxiety and depression were respectively, $34.7 \%$ and $12.2 \%$. We observed statistically significant differences between the groups with and without anxiety in the domains: General Health, Mental Health, and Vitality. Between the groups with and without depression there were statistically significant differences in the General Health and Mental Health domains. Conclusion: Patients showed great expectation to surgical treatment and the symptoms of anxiety and depression were related to some domains of HRQoL. Thus, the study contributes to broaden our knowledge and we can therefore guide the patients as to their expectations with respect to the real possibilities arising from surgery.
\end{abstract}

Keywords: Spine; Questionnaires; Spinal stenosis; Quality of life; Life expectancy.

\section{RESUMO}

Objetivo: Avaliar as expectativas de pacientes que aguardavam o tratamento cirúrgico da estenose do canal lombar e a associação da qualidade de vida relacionada à saúde (QVRS) aos sintomas de ansiedade e depressão. Métodos: Amostra de 49 pacientes de um hospital universitário. A QVRS foi avaliada pelo questionário Oswestry (ODI) e pelo SF-36, e os sintomas de ansiedade e depressão, por meio das subescalas Hospital Anxiety and Depression Scale (HADS). As expectativas foram investigadas por meio de questões usadas em estudos internacionais. Os dados foram analisados descritivamente e pelo teste $t$ de Student. Resultados: O tempo médio de evolução da doença foi de 34,5 meses, a média de idade foi 58,8 anos e 55,1\% eram mulheres. A maioria dos pacientes tinha a expectativa de melhorar com o tratamento cirúrgico e 46,9\% esperavam ficar "muito melhores" com relação à dor nas pernas, capacidade de caminhar, independência nas atividades e bem estar mental. Os escores de sintomas de ansiedade e depressão foram respectivamente de 34,7\% e 12,2\%. Obsenvamos diferenças estatisticamente significantes entre os grupos com e sem ansiedade nos domínios: estado geral de saúde, saúde mental e vitalidade. Entre os grupos com e sem depressão as diferenças foram estatisticamente significantes no domínio de estado geral de saúde e saúde mental. Conclusão: Os pacientes apresentaram grande expectativa frente ao tratamento cirúrgico e os sintomas de ansiedade e depressão eram relacionados com alguns domínios do QVRS. Desta forma, o estudo contribui para ampliarmos o nosso conhecimento e podermos, assim, orientar os pacientes quanto às suas expectativas com relação às reais possibilidades advindas da cirurgia.

Descritores: Coluna vertebral; Questionários; Estenose espinhal; Qualidade de vida; Expectativa de vida.

\section{RESUMEN}

Objetivos: Evaluar las expectativas de los pacientes en espera de tratamiento quirúrgico de la estenosis del canal lumbar y la asociación de la calidad de vida relacionada con salud (CVRS) con síntomas de ansiedad y depresión. Métodos: La muestra incluyó a 49 pacientes de un hospital universitario. La CVRS se evaluó mediante el cuestionario de Oswestry (ODI) y SF-36 y los síntomas de ansiedad y depresión por la Hospital Anxiety and Depression Scale (HADS). Las expectativas fueron investigadas por medio de preguntas utilizadas en estudios internacionales. Los datos se analizaron de forma descriptiva y mediante la prueba $t$ de Student. Resultados: El tiempo promedio de la progresión de la enfermedad fue de 34,5 meses, la edad media fue 58,8 años y el 55,1\% eran mujeres. La mayoría de los pacientes tenían la expectativa de mejorar con el tratamiento quirúrgico y el 46,9\% esperan quedarse "mucho mejor" en materia de dolor en las piernas, capacidad de caminar, independencia en las actividades y el bienestar mental. Las puntuaciones de ansiedad y depresión fueron respec-

1. Department of Biomechanics, Medicine and Rehabilitation, Faculdade de Medicina de Ribeirão Preto, Universidade de São Paulo, Ribeirão Preto, SP, Brazil.

2. Escola de Enfermagem de Ribeirão Preto, Universidade de São Paulo, Ribeirão Preto, SP, Brazil.

Study conducted at the Hospital das Clínicas da Faculdade de Medicina de Ribeirão Preto, USP, Ribeirão Preto, SP, Brazil. Correspondence: Av. Bandeirantes, 3900, $11^{\circ}$ Andar, Monte Alegre, Ribeirão Preto, SP. Brasil. 1404-900. lipacola@ usp.br 
tivamente, 34,7\% y 12,2\%. Se observaron diferencias estadísticamente significativas entre los grupos con y sin ansiedad en los dominios Salud General, Salud Mental y Vitalidad. Entre los grupos con y sin depresión se constataran diferencias significativas en los dominios de Salud General y Salud Mental. Conclusión: Los pacientes mostraron gran expectativa con relación al tratamiento quirúrgico y los síntomas de ansiedad y depresión se relacionaron con algunos dominios de la CVRS. Así, el estudio contribuye a ampliar nuestros conocimientos y podemos así guiar a los pacientes en cuanto a sus expectativas frente a las posibilidades reales que surgen de la cirugía.

Descriptores: Columna vertebral; Cuestionarios; Estenosis espinal; Calidad de vida; Esperanza de vida.

\section{INTRODUCTION}

Spinal stenosis is defined as the narrowing of the diameter of the vertebral canal, nerve root canal, or intervertebral foramen. Lumbar canal stenosis (LCS) may have different etiologies (congenital, idiopathic, degenerative, iatrogenic, post-traumatic, spondylolisthetic, metabolic). The acquired and degenerative type is the most common, and the nerve and vascular structures contained within the spinal canal are compressed as a consequence of degenerative changes of the vertebral segment. ${ }^{1}$ Neurogenic claudication is one of the clinical manifestations of lumbar canal stenosis ${ }^{2}$ that contributes to the functional disability of patients and has a significant impact on functional capacity, quality of life, and independence. ${ }^{3-5}$

Surgical treatment has been indicated in patients with spinal canal stenosis, accompanied by neurogenic claudication or incapacitating painful symptoms that are resistant to conservative treatment. 6,7 Patients who suffer from the limitations arising from LCS and the symptoms resulting from this condition, especially pain, ${ }^{8}$ have high expectations of improvement in their quality of life after surgical treatment.

Mancuso et $\mathrm{al} . .^{9}$ defined the expectations of patients to be the level of improvement in relation to the condition prior to surgery (absolute change of function postoperatively), also considering the time required for there to be a functional gain and an improvement of their condition postoperatively. The involvement of the patient in the discussion of expectations within the context of spinal diseases has led researchers to study the general aspects of spinal problems, such as adherence and response to treatment, disability, and rehabilitation, among others. ${ }^{10,11}$

Thus, the impact of the disease on daily activities and expectations regarding the proposed surgery have also been evaluated by instruments, which led to identifying the factors that may influence the surgical results. ${ }^{12}$

The aim of this study was to evaluate the expectations of patients awaiting surgical treatment of lumbar canal stenosis and the association of health-related quality of life (HRQoL) with the presence of symptoms of anxiety and depression.

\section{MATERIALS AND METHODS}

The study was observational, analytical and cross-sectional. It was conducted at the Hospital das Clínicas da Faculdade de Medicina de Ribeirão Preto, USP. Forty-nine patients were interviewed from August 2011 to June 2013, awaiting surgery for treatment of LCS. The project was approved by the Research Ethics Committee of the institution where the study was conducted.

The HRQoL was assessed by the Oswestry Low Back Pain Disability Questionnaire (ODI) ${ }^{13}$ in its version that was adapted for Portuguese. ${ }^{14}$ The instrument assesses the functional limitations perceived by patients with low back pain using 10 sections, the first of which assesses the intensity of pain, and the others ascertain the constraints caused by the pain in performing the following daily activities: providing personal care, lifting objects, walking, sitting and standing, sleeping, sexual life, social life, and locomotion. Each section has six statements with a score ranging from zero to five points. After the completion of the 10 sections, the score is calculated by dividing the value obtained by the maximum possible amount (50) multiplied $100 \%{ }^{15}$ The result is evaluated on a scale from $0 \%$ to $100 \%$, and the scores from $0 \%$ to $20 \%$ represent minimal disability, $21 \%$ to $40 \%$, moderate disability, $41 \%$ to $60 \%$, severe disability, $61 \%$ to $80 \%$ indicate invalid patients, and from $81 \%$ to $100 \%$ the patients are restricted to the bed. ${ }^{7,12}$

HRQoL was also assessed by the generic Medical Outcomes Survey Short Form 36 items (SF-36), ${ }^{16}$ one of the most widely used in the medical literature. The version used was that which was adapted for Brazil. ${ }^{17}$ It consists of 36 items grouped into eight scales or domains: functional capacity (10 items), physical aspects (four), pain (two), general health (five), vitality (four), social functioning (two), emotional aspects (three), mental health (five), and one question for the comparative evaluation of the assessment of the current health condition of the individual and the condition one year prior. The instrument purports to assess both the negative aspects of health (disease or illness) and the positive aspects (welfare) and to respond to its items (except the comparative question, with the time span of one year), The respondent must consider the last four weeks, which justifies the choice of this instrument in our study. The values of each domain are normalized on a scale of zero to 100. Low numerical values reflect a poorer quality of life related to health. ${ }^{16}$

The presence of symptoms of anxiety and depression were assessed using the subscales of the Hospital Anxiety and Depression Scale (HADS) $)^{18}$ in its adapted version. ${ }^{19}$ The scale consists of 14 items, seven aimed at assessing anxiety (HAD-A), and seven for the evaluation of depression (HAD-D). The response values range from zero to three, the sum of the subscales can range from zero to 21 points. Thus, the evaluation of the responses can be made with the total value of each subscale, and the higher the value, the greater the emotional disorder, considering both of the subscales, anxiety and depression. For patients with spinal problems, the following classification has been adopted: for anxiety, values ranging from zero to eight for the category "no symptoms" and nine or more for the category "with symptoms." For depression, the values are from zero to nine for the category "no symptoms" and ten or more for the category "with symptoms."7

The surgical treatment expectations of patients were obtained by adapting the questionnaire proposed in the study by Mannion et al., ${ }^{20}$ which inquired of the patient, "What changes do you expect to occur with the surgery outcome?" (Try to think of what really is possible and not what you want to happen). The participant was asked to answer this question by considering each of the eight items that may undergo changes after surgical treatment: 1) pain in the legs; 2) back pain, 3) ability to walk, 4) independence for daily activities, 5) sports activities (including walking to keep fit), 6) physical capacity in general (at work and at home), 7) frequency and quality of social contacts, and 8) mental well-being. Response options presented to participants in the evaluation of each of the items were: much better (5), better (4), slightly better (3), no improvement (2), and worse (1). A sixth option, "not applicable," was provided for the cases in which the item was absent in the evaluation of patients.

The data were processed using the IBM SPSS ${ }^{\circledR}$ version 21 for Windows and analyzed descriptively. We used the Student's t-test to compare the HRQoL measures according to the presence of symptoms of anxiety and depression. The significance level was 0.05 .

\section{RESULTS}

Forty-nine patients were interviewed with stenosis of the lumbar spine and indication for surgical treatment. The mean age of patients was 58.8 years $(S D=12.5)$, ranging from 32 to 86 years, and there was female predominance $(55.1 \%)$. (Table 1$)$

The expectations of the patients in the preoperative period for 
surgical treatment are presented in Table 2. According to the results we observed that most patients expected some improvement (ranging from "slightly better" to "much better") after surgery; $44.9 \%$ or more of respondents expected to be "better" regarding the symptoms pain, performing sports activities, social activities, and physical ability; $46.9 \%$ or more of participants expected to be "much better" in the items leg pain, walking ability, independence in daily activities, and mental well-being.

The HRQoL evaluation results showed that the most affected domains of the SF-36 were related to physical activities such as physical aspects and functional capacity. (Table 3)

Regarding HRQoL, the assessment of the ODI makes it possible to detect the clinical and functional limitations of patients.

Table 1. Sociodemographic and clinical characterization of patients with diseases of the lumbar spine $(n=49)$.

\begin{tabular}{c|c|c}
\hline Variables (n=49) & $\begin{array}{c}\text { Mean (SD) } \\
\text { Number (\%) }\end{array}$ & $\begin{array}{c}\text { Median } \\
\text { (interval) }\end{array}$ \\
\hline Age in years, mean (SD) & $58.8(12.5)$ & $58.9(32-86)$ \\
\hline Sex & & \\
\hline Female & $27(55.1)$ & \\
\hline Male & $22(44.9)$ & \\
\hline Time of evolution of the disease (months) & $34.5(22.8)$ & $28(8-120)$ \\
\hline Treatment performed up to the present & & \\
\hline Pharmacological and physiotherapeutic & $30(61.2)$ & \\
\hline Epidural block & $10(20.4)$ & \\
\hline Pharmacological & $6(12.2)$ & \\
\hline Other & $3(6.1)$ & \\
\hline
\end{tabular}

Table 2. Distribution of the 49 patients in relation to expectations regarding surgical treatment.

\begin{tabular}{|c|c|c|c|c|c|c|}
\hline \multirow[t]{2}{*}{ Questions } & $\begin{array}{l}\text { Much } \\
\text { better }\end{array}$ & Better & $\begin{array}{c}\text { Slightly } \\
\text { better }\end{array}$ & $\begin{array}{c}\text { No } \\
\text { improvement }\end{array}$ & Worse & $\begin{array}{c}\text { Not } \\
\text { applicable }\end{array}$ \\
\hline & $\mathbf{N}(\%)$ & $\mathbf{N}(\%)$ & $\mathbf{N}(\%)$ & $\mathrm{N}(\%)$ & N (\%) & $\mathbf{N}(\%)$ \\
\hline 1 - Pain in the legs & $23(46.9)$ & $22(44.9)$ & $4(8.2)$ & - & - & - \\
\hline 2 - Back pain & 15 (30.6) & $25(51)$ & $5(10.2)$ & - & - & $4(8.2)$ \\
\hline 3 - Ability to walk & 29 (59.2) & $14(28.6)$ & $6(12.2)$ & - & - & - \\
\hline $\begin{array}{l}4 \text { - Independence } \\
\text { in daily activities }\end{array}$ & $26(53.1)$ & $20(40.8)$ & $3(6.1)$ & - & - & - \\
\hline $\begin{array}{l}5 \text { - Sports } \\
\text { activities }\end{array}$ & $18(36.7)$ & $26(53.1)$ & $3(6.1)$ & - & - & $2(4.1)$ \\
\hline $\begin{array}{l}6 \text { - General } \\
\text { physical ability }\end{array}$ & $18(36.7)$ & $22(44.9)$ & $9(18.4)$ & - & - & - \\
\hline $\begin{array}{l}7 \text { - Frequency and } \\
\text { quality of social } \\
\text { contacts }\end{array}$ & $16(32.7$ & $30(61.2)$ & $2(4.1)$ & $1(2)$ & - & - \\
\hline $\begin{array}{l}8 \text { - Mental } \\
\text { well-being }\end{array}$ & $23(46.9)$ & $24(49)$ & $2(4.1)$ & - & - & - \\
\hline
\end{tabular}

Table 3. Results of the assessment of quality of life related to health by the SF-36 of the 49 patients.

\begin{tabular}{c|c|c|c}
\hline SF-36 domains & Interval obtained & Median & Mean (SD) \\
\hline General health status & $5-100$ & 72 & $70.9(16.7)$ \\
\hline Mental health & $24-92$ & 56 & $61.5(18)$ \\
\hline Pain & $20-90$ & 70 & $60.6(16.1)$ \\
\hline Vitality & $10-100$ & 50 & $52.6(20.6)$ \\
\hline Social aspects & $0-88$ & 50 & $45.9(18.3)$ \\
\hline Emotional aspects & $0-100$ & 33.3 & $39.5(35.8)$ \\
\hline Functional capacity & $0-60$ & 25 & $24.4(12.5)$ \\
\hline Physical aspects & $0-50$ & 0 & $6.6(14.2)$ \\
\hline
\end{tabular}

The average obtained from the participants was $51.3 \%$. The assessment showed that $57.1 \%$ had severe disability, with pain being the primary disability, and $20.4 \%$ presented as invalids. With regard to the psychological well-being of patients, we found the presence of symptoms of anxiety and depression in $34.7 \%$ and $12.2 \%$, respectively, of the respondents.

The difference in HRQoL according to the presence of symptoms of anxiety and depression was assessed by comparing the mean of SF-36 domains between groups (with and without symptoms). (Table 4)

Regarding the anxiety of the patients awaiting surgery, by comparing the means of the SF-36 domains in the presence or absence of symptoms, the group with symptoms was observed to have lower averages than the group without symptoms in six of the eight domains, indicating a worse HRQoL. Only in the pain and functional capacity domains did the group with symptoms have higher averages than the group without symptoms, 65.9 and 57.8, respectively, and 25.9 and 23.6. However, the difference between groups was statistically significant only in the general health $(p=0.01)$, mental health $(p=0.003)$, and vitality $(p=0.04)$ domains.

Similar results were observed when we compared the HRQoL according to the presence of symptoms of depression. In seven of the eight domains of the SF-36, the group without symptoms had higher averages than patients with symptoms, with the exception of the social aspects domain. In this domain, the mean was 50 for the group with depressive symptoms, and 45.3 for the group without symptoms. The differences between groups were also statistically significant in the general health $(p=0.022)$ and mental health $(p=0.001)$ domains.

\section{DISCUSSION}

In recent years, the assessment of treatment from the perspective of patients has been encouraged, and recent studies have considered subjective measures of symptoms and questionnaires on the quality of life of patients.

In our study there was a predominance of females, as in other studies. ${ }^{7,21,22}$

The choice of the HADS was due to its ease of use, fast execution (ten minutes average time), and the ability of the questionnaire to be answered by the patient. This study showed a $34.7 \%$ prevalence of symptoms of HAD-A anxiety. Also, the fact that it does not contain items assessing somatic symptoms and that its validity and reliability have been demonstrated in several studies was also important for it as our choice. In a prospective cohort study, Toyone et al. ${ }^{23}$ described verifying the presence of symptoms of depression and anxiety in the preoperative period to be of utmost importance, since depressed patients tend to have lower expectations and therefore less satisfaction with surgical results. In a study using the same instrument, the authors observed symptoms of anxiety in $40.1 \%$ and depression in $17.4 \%$ of cases. ${ }^{7}$

The expectations of patients, their characteristics, and assessments of psychosocial factors should be integrated into any treatment plan for lumbar canal stenosis, as these can determine which patients will benefit from the proposed surgical treatment. ${ }^{24,25}$

In our study, like that of Mannion et al., ${ }^{20}$ after being questioned about expectations, $40 \%$ of patients were overly optimistic, considering the improvement of the following items: leg pain, walking ability, independence in daily activities, and mental well-being. This percentage increased to $50 \%$ when evaluating the results related to sports activities, back pain, social contacts, and physical ability. These results showed that the expectations of patients before surgery may influence or determine outcomes, in some cases assisting in the improvement or rehabilitation of patients.

Another important variable studied was the Oswestry Disability Index (ODI) Questionnaire, which provides data on the impact of back pain on daily activities. In the study group, the results found were similar to those described in other studies. ${ }^{26-28}$

The results of the HRQoL obtained by the SF-36 indicated that 
Table 4. Comparison of the means of the SF-36 domains, according to the presence of symptoms of anxiety and depression.

\begin{tabular}{|c|c|c|c|c|c|c|}
\hline HRQoL & \multicolumn{3}{|c|}{ Anxiety } & \multicolumn{3}{|c|}{ Depression } \\
\hline SF-36 domains & $\begin{array}{c}\text { No symptoms (n=32) } \\
M \text { (SD) } \\
\end{array}$ & $\begin{array}{l}\text { With symptoms } \\
(n=17) M(S D)\end{array}$ & P value* & $\begin{array}{c}\text { No symptoms ( } n=43 \text { ) } \\
M(S D)\end{array}$ & $\begin{array}{c}\text { With symptoms }(\mathrm{n}=6) \\
M(S D)\end{array}$ & $P$ value* \\
\hline General health status & $75.8(13.7)$ & $61.6(18.4)$ & 0.01 & $72.4(17)$ & $60(9.4)$ & 0.022 \\
\hline Pain & $57.8(16.4)$ & $65.9(14.6)$ & 0.08 & $61.4(16)$ & 55 (17.6) & 0.43 \\
\hline Vitality & $56.9(21)$ & 44.7 (18) & 0.04 & $54.5(20.4)$ & $39.2(17.4)$ & 0.09 \\
\hline Functional capacity & 23.6 (13) & $25.9(11.8)$ & 0.53 & $24.8(12.6)$ & $21.7(12.1)$ & 0.57 \\
\hline Physical aspects & $8.6(16.3)$ & $2.94(8.3)$ & 0.11 & $6.98(14.8)$ & $4.17(10.2)$ & 0.56 \\
\hline
\end{tabular}

* $p$ value from the Student's t-test.

the domains most affected were those related to physical activities like physical aspects and functional capacity, and those that were better evaluated were the general health and mental health. These results were similar to those reported in other studies. ${ }^{7,24}$

Diseases of the cervical or lumbar spine have a large impact on both the physical and mental HRQoL domains. The disabilities caused by diseases negatively impact the HRQoL and are associated with a high prevalence of depressive symptoms. ${ }^{29}$

In using the SF-36 to assess the perceived health status of patients undergoing decompression, the physical component score showed that patients had high expectations for surgery, and reported significant postoperative improvements regarding this component. ${ }^{30}$

\section{CONCLUSION}

The evaluation showed high expectations of patients regarding surgical treatment, and symptoms of anxiety and depression were related to some domains of health-related quality of life. The questionnaires can assist in the selection of patients for surgical treatment, so that we can thus become acquainted with their expectations regarding the real possibilities arising from surgery.

All authors declare no potential conflict of interest concerning this article.

\section{REFERENCES}

1. Sirvanci M, Bhatia M, Ganiyusufoglu KA, Duran C, Tezer M, Ozturk C, et al. Degenerative lumbar spinal stenosis: correlation with Oswestry Disability Index and MR imaging. Eur Spine J. 2008;17(5):679-85.

2. Verbiest $H$. A radicular syndrome from developmental narrowing of the lumbar vertebral canal. J Bone Joint Surg Br. 1954;36-B(2):230-7.

3. Ciricillo SF, Weinstein PR. Lumbar spinal stenosis. West J Med. 1993;158(2):171-7.

4. Lang $\mathrm{E}$, Hilz MJ, Erxleben $\mathrm{H}$, Ernst M, Neundörfer B, Liebig K. Reversible prolongation of motor conduction time after transcranial magnetic brain stimulation after neurogenic claudication in spinal stenosis. Spine (Phila Pa 1976). 2002;27(20):2284-90.

5. Park DK, An HS, Lurie JD, Zhao W, Tosteson A, Tosteson TD, et al. Does multilevel lumbar stenosis lead to poorer outcomes?: a subanalysis of the Spine Patient Outcomes Research Trial (SPORT) lumbar stenosis study. Spine (Phila Pa 1976). 2010;35(4):439-46.

6. Brandt RA, Wajchenberg M. Estenose do canal vertebral cervical e lombar. Einstein. 2008:6(S1):S29-S32.

7. Falavigna A, Righesso-Neto O, Teles AR. Avaliação clínica e funcional no pré-operatório de doenças degenerativas da coluna vertebral. Coluna/Columna. 2009;8(3):245-53.

8. Deyo RA, Battie M, Beurskens AJ, Bombardier C, Croft P, Koes B, et al. Outcome measures for low back pain research. A proposal for standardized use. Spine (Phila Pa 1976). 1998 Sep 15;23(18):2003-13

9. Mancuso CA, Salvati EA, Johanson NA, Peterson MG, Charlson ME. Patients' expectations and satisfaction with total hip arthroplasty. J Arthroplasty. 1997;12(4):387-96.

10. Resnik L, Dobrykowski E. Outcomes measurement for patients with low back pain. Orthop Nurs. 2005;24(1):14-24

11. Tekin B, Unver B, Karatosun V. Expectations in patients with total knee arthroplasty. Acta Orthop Traumatol Turc. 2012;46(3):174-80.

12. Falavigna A, Teles AR, Braga GL, Barazzetti L, Tregnano AC. Instrumentos de avaliação clínica e funcional em cirurgia da coluna vertebral. Coluna/Columna. 2011:10(1):62-7.

13. Fairbank JC, Pynsent PB. The Oswestry Disability Index. Spine (Phila Pa 1976). 2000;25(22):2940-52

14. Vigatto R, Alexandre NM, Correa Filho HR. Development of a Brazilian Portuguese version of the Oswestry Disability Index: cross-cultural adaptation, reliability, and validity. Spine (Phila Pa 1976). 2007;32(4):481-6.

15. Roland M, Fairbank J. The Roland-Morris Disability Questionnaire and the Oswestry Disability Questionnaire. Spine (Phila Pa 1976). 2000;25(24):3115-24.

16. Ware JE Jr, Sherbourne CD. The MOS 36-item short-form health survey (SF-36). I. Conceptual framework and item selection. Med Care. 1992;30(6):473-83.
17. Cicconelli R M, Ferraz MB, Santos W, Meinão I, Quaresma MR. Tradução para a língua portuguesa e validação do questionário genérico de avaliação de qualidade de vida SF-36 (Brasil SF-36). Rev Bras Reumatol. 1999:39(3):143-50.

18. Zigmond AS, Snaith RP. The hospital anxiety and depression scale. Acta Psychiatr Scand. 1983;67(6):361-70

19. Botega N J, Bio MR, Zomignani MA, Gracia -Junior RC, Pereira WAB. Validação da escala hospitalar de ansiedade e depressão (HAD) em pacientes epilético ambulatoriais. J Bras Psiquiatria. 1998;6(47):285-9.

20. Mannion AF, Junge A, Elfering A, Dvorak J, Porchet F, Grob D. Great expectations: really the novel predictor of outcome after spinal surgery? Spine (Phila Pa 1976). 2009:34(15):1590-9

21. Sinikallio $S$, Aalto T, Koivumaa-Honkanen $H$, Airaksinen $O$, Herno A, Kröger $H$, et al. Life dissatisfaction is associated with a poorer surgery outcome and depression among lumbar spinal stenosis patients: a 2-year prospective study. Eur Spine J. 2009:18(8):1187-93.

22. Bouras T, Stranjalis G, Loufardaki M, Sourtzis I, Stavrinou LC, Sakas DE. Predictors of long-term outcome in an elderly group after laminectomy for lumbar stenosis. J Neurosurg Spine. 2010:13(3):329-34

23. Toyone T, Tanaka T, Kato D, Kaneyama R, Otsuka M. Patients' expectations and satisfaction in lumbar spine surgery. Spine (Phila Pa 1976). 2005;30(23):2689-94.

24. Yee A, Adjei N, Do J, Ford M, Finkelstein J. Do patient expectations of spinal surgery relate to functional outcome? Clin Orthop Relat Res. 2008;466(5):1154-61.

25. Athiviraham A, Wali ZA, Yen D. Predictive factors influencing clinical outcome with operative management of lumbar spinal stenosis. Spine J. 2011;11(7):613-7.

26. Carreon LY, Berven SH, Djurasovic M, Bratcher KR, Glassman SD. The discriminative properties of the SF-6D compared with the SF-36 and ODI. Spine (Phila Pa 1976). 2013;38(1):60-4.

27. Zouboulis $P$ Karageorgos $A$, Dimakopoulos $P$, Tyllianakis $M$, Matzaroglou $C$, Lambiris $E$. Functional outcome of surgical treatment for multilevel lumbar spinal stenosis. Acta Orthop. 2006;77(4):670-6.

28. Shabat S, Miller LE, Block JE, Gepstein R. Minimally invasive treatment of lumbar spina stenosis with a novel interspinous spacer. Clin Interv Aging. 2011;6:227-33.

29. Boakye M, Moore R, Kong M, Skirboll SL, Arrigo RT. Health-related quality-of-life status in Veterans with spinal disorders. Qual Life Res. 2013;22(1):45-52.

30. Bechara AHS et al . Evolução dos questionários Oswestry 2.0 e do componente físico (PCS) do SF-36 durante o primeiro ano de pós-operatório de artrodese da coluna lombar em doença degenerativas. Coluna/Columna. 2013;12(2):128:32. 